\title{
Measurement of Oncostatin M, Leukemia Inhibitory Factor, and Interleukin-11 Levels in Serum, Saliva, and Gingival Crevicular Fluid of Patients with Periodontal Diseases
}

\author{
Periodontal Hastalıklı Bireylerde Serum, Tükürük ve Diş Eti Oluğu \\ SIVIsında Onkostatin M, Lösemi İnhibitör Faktör ve Interlökin-11 \\ Seviyelerinin Incelenmesi
}

(D) Tuğba Aydın, (D) Alparslan Dilsiz

Atatürk University Faculty of Dentistry, Department of Periodontology, Erzurum, Turkey

Keywords
Chronic periodontitis, interleukin-11,
leukemia inhibitory factor, oncostatin M,
periodontal therapy
Anahtar Kelimeler
Kronik periodontitis, interlökin-11, lösemi
inhibitör faktör, onkostatin M, periodontal
tedavi

Received/Geliş Tarihi : 13.01.2021

Accepted/Kabul Tarihi : 17.02.2021

doi:10.4274/meandros.galenos.2021.50251

Address for Correspondence/Yazışma Adresi: Tuğba Aydın Ph.D.,

Atatürk University Faculty of Dentistry,

Department of Periodontology, Erzurum, Turkey

Phone : +90 5358388532

E-mail : dtkoseoglu@hotmail.com

ORCID ID: orcid.org/0000-0002-9675-5509

(C) Meandros Medical and Dental Journal, Published by Galenos Publishing House.

This is article distributed under the terms of the

Creative Commons Attribution NonCommercial 4.0

International Licence (CC BY-NC 4.0).

\begin{abstract}
Objective: This study aimed to determine oncostatin M (OSM), interleukin-11 (IL11), and leukemia inhibitory factor (LIF) levels in gingival crevicular fluid (GCF), saliva, and serum in periodontally healthy individuals and those with gingivitis (G) and chronic periodontitis (CP) before and after periodontal treatment and to evaluate the relationship between these cytokine levels and clinical periodontal parameters.

Materials and Methods: This study involved 24 patients with healthy $(H)$ periodontal tissues, 24 patients with $\mathrm{G}$, and 24 patients with CP. Initially, GCF, saliva, and serum samples were collected, and clinical periodontal measurements, including the plaque index, gingival index, probing depth, and clinical attachment levels, were recorded. At 8 weeks after the initial periodontal treatment, the abovementioned parameters were recorded in the $\mathrm{G}$ and $\mathrm{CP}$ groups. Cytokine levels were determined using enzyme-linked immunosorbent assay.

Results: OSM levels in the GCF, saliva, and serum were significantly higher in the CP group $(p<0.05)$ than in other groups. LIF levels in GCF exhibited a significant increase $(p<0.05)$ in the CP group; however, no significant difference was found in the serum and saliva LIF levels among groups ( $p>0.05)$. IL-11 levels were significantly higher in the CP group $(\mathrm{p}<0.05)$ than in other groups, but no significant difference was noted in the serum IL-11 levels among the groups ( $p>0.05)$. Similarly, saliva IL-11 levels were significantly higher in the CP group than in the $\mathrm{H}$ group $(p<0.05)$, but they did not show significant difference between the CP and $\mathrm{G}$ groups ( $p>0.05)$. Comparative analysis of GCF, saliva OSM, and IL-11 levels in the G and CP groups before and after initial periodontal therapy revealed that they are significantly lower in both groups after therapy $(\mathrm{p}<0.05)$.

Conclusion: Levels of OSM, LIF, and IL-11 are higher in the $\mathrm{G}$ and CP groups, which indicate periodontal tissue destruction. Decreases in IL-11, OSM, and LIF levels after treatment support the idea that initial periodontal therapy can inhibit periodontal tissue destruction.
\end{abstract}


Öz

Amaç: Bu çalışmanın amacı periodontal açıdan sağlıklı, gingivitisli ve kronik periodontitisli bireylerde tedavi öncesi ve sonrasında diş eti oluğu sıvısı (DOS), serum ve tükürükte onkostatin M (OSM), lösemi inhibitör faktör (LIF) ve interlökin-11 (IL-11) seviyelerini tespit etmek ve klinik periodontal parametreler ile adı geçen bu sitokin seviyeleri arasındaki ilişkiyi araştırmaktır.

Gereç ve Yöntemler: Bu çalışmaya 24 periodontal olarak sağlıklı, 24 gingivitisli (G) ve 24 kronik periodontitisli (CP) birey dahil edildi. Başlangıçta tüm gruplardan DOS, serum ve tükürük örnekleri alındı ve plak indeksi (Pi), gingival indeks (Gi), sondalanabilir cep derinliği (SCD) ve klinik ataşman kaybı (KAK) değerlerini içeren klinik periodontal ölçümler kaydedildi. G ve CP gruplarında başlangıç periodontal tedaviden 8 hafta sonra veriler tekrar kaydedildi. Sitokin düzeyleri enzime bağlı immünosorbent testi metoduyla saptandı. Bulgular: DOS, serum ve tükürük OSM seviyeleri CP grubunda diğer gruplara göre anlamlı derecede yüksek bulundu $(p<0,05)$. DOS LIF seviyeleri CP grubunda diğer gruplara göre anlamlı derecede yüksek bulunurken $(p<0,05)$, serum ve tükürük LIF seviyeleri gruplar arasında farklılık göstermedi $(p>0,05)$. DOS IL-11 seviyeleri CP grubunda diğer gruplara kıyasla anlamlı derecede yüksek bulundu $(p<0,05)$. Serum IL-11 seviyeleri gruplar arasında farklılık göstermedi $(p>0,05)$. Tükürük IL-11 seviyeleri CP grubunda $\mathrm{H}$ grubuna göre anlamlı derecede yüksek bulunurken $(p<0,05), G$ grubu ile fark saptanmadı $(p>0,05)$. G ve CP gruplarında başlangıç periodontal tedavi öncesi ile karşılaştırıldığında, tedavi sonrası DOS ve tükürük OSM ve IL-11 seviyelerinin istatistiksel olarak anlamlı derecede düşük olduğu bulundu $(p<0,05)$.

Sonuç: OSM, LIF ve IL-11 seviyelerinin G ve CP gruplarında yüksek bulunması periodontal doku yıkımının mevcudiyetini göstermektedir. Tedavi sonrası OSM, LIF ve IL-11 seviyelerindeki azalma periodontal başlangıç tedavisinin periodontal doku yıkımını engelleyebileceğini desteklemektedir.

\section{Introduction}

Periodontitis, which is the most common form of periodontal disease, is defined by alveolar bone and periodontal attachment damage and refers to an inflammation spreading from the gingival edge to the periodontal supporting tissues. The primary etiologic agent for periodontitis is dental plaque bacteria. However, in explaining the formation of periodontal disease, it has been stated that only addressing the presence of bacteria is not sufficient; besides that, interactions between bacteria and host defense systems have also contributed to the development and progression of the disease. When cells of the host defense systems encounter microbial dental plaque and bacteria products, both tissue destructive and protective mechanisms are activated simultaneously. Periodontal tissue destruction mainly occurs in the absence of protective mechanisms (1).

The synthesis and release of pro-inflammatory and immuno-secretory cytokines resulting from microorganisms' interaction with host tissue cells play an essential role in periodontal disease (2). Those are also responsible for many pathological tissue changes, from connective tissue destruction to bone loss. Some cytokines are crucial in diagnosing periodontal destruction and determining its progression (3). Oncostatin M (OSM), an interleukin-6 (IL-6) family member, belongs to the glycoprotein (gp)130 cytokine receptor subunit. Gp130 is a common receptor subunit for the IL-6 family of cytokines, including primarily IL6, OSM, leukemia inhibitory factor (LIF), and IL-11, and capable of intracellular signaling required for a wide range of cellular action (4).

Gp130 cytokines are synthesized by immune and non-immune cells and affect hematopoietic, immunological, and inflammatory cellular communications (5). Their common feature is that they use the gp130 molecule as a signaling molecule to interact with receptor complexes on the cell surface. Thus, IL-6, OSM, LIF, and IL-11 induce responses caused by receptor complexes dependent on gp130 and the biological responses associated with them (6).

It is a known fact that bone metabolism depends on the balance between osteoblastic and osteoclastic activities. Previous studies on gp130 cytokines have reported that these cytokines play a role in both osteoblastic and osteoclastic activities, affecting bone metabolism (4). OSM can cause bone resorption by acting through autocrine IL- 6 and paracrine receptor activator of NF-KB ligand regulation on osteoblasts and osteoclasts. It can also upregulate the production of matrix metalloproteinase (MMP) or increase the production of IL- 6 by acting synergistically with IL- 6 and tumor necrosis factor-alpha. In this way, it can lead to alveolar bone resorption in periodontitis (7). It has also been described that there is a positive correlation between the severity of periodontal disease and the gingival crevicular fluid (GCF) OSM level (8). 
LIF, another gp130 cytokine, has functions similar to OSM. In humans, information about LIF and OSM cycle in skeletal tissue is limited (9). LIF and OSM have been shown to play roles in bone remodeling and the regulation of bone cell functions in mouse calvarial bone cultures (10). Richards et al. (11), too, demonstrated that OSM and LIF have a critical potential role in regulating osteoclast formation and osteoblast activation in mouse bone marrow and calvaria cells.

IL-11 has been evaluated as a possible molecule for therapeutic modulation of host response in treating periodontal disease (12). By showing antiinflammatory effect of IL-11 for the inhibition of some pro-inflammatory cytokines; it has been shown to stimulate bone resorption by increasing osteoclast formation and osteoblast mediated osteoid degradation (13). This cytokine also regulates inflammation by stimulating MMP-1 tissue inhibitor in synoviocytes and chondrocytes, similar to IL-6, too (14).

While clinical measurements can provide important information about periodontal disease's severity, they cannot give necessary information about the disease's activation. Therefore, GCF, blood, and saliva samples should be analyzed together to evaluate periodontal disease activity accurately (15).

This study's hypothesis is to demonstrate the detectability of OSM, LIF, and IL-11 in GCF, as well as in serum and saliva, and the preventability of tissue destruction by changes in the levels of these cytokines after nonsurgical periodontal therapy.

The aim of our study is to detect OSM LIF and IL-11 levels in GCF serum and saliva in individuals with periodontally healthy gingivitis $(G)$ and chronic periodontitis (CP) before and after periodontal treatment and to investigate the relationship between clinical periodontal parameters and the levels of these cytokines.

\section{Materials and Methods}

\section{Study Population}

Systemically healthy 72 individuals, regardless of gender, applied to Atatürk University Faculty of Dentistry Department of Periodontology from 2014 March to 2014 August were enrolled in the study and were defined as healthy, $\mathrm{G}$, and $\mathrm{CP}$ individuals based on clinical examination and radiographic analysis. This study was performed after Atatürk University Faculty of Dentistry Ethics Committee (decision no: 22/2014, date: 01.08.2014) approval was obtained. The research was conducted under the Helsinki Declaration of 1975 (revised in 2000). Informed consent form was given to each individual. Systemic and dental anamnesis were provided from all participants. Patients with any systemic disease and condition, those taking any medication, those with acute complaints, those who have undergone periodontal treatment within the past six months, smokers, and patients with caries and/or restoration in teeth to be taken GCF sample were excluded. Patients were added if they had $\geq 16$ teeth.

The patients' selection was made according to the diagnostic criteria proposed by the International Symposium on Classification of Periodontal Diseases and Conditions 1999 (16). Study participants were divided into three groups, as outlined below.

Healthy group (group $H) \quad(n=24)$ included individuals with probing depth (PD) $\leq 3 \mathrm{~mm}$, no sites with attachment loss, and no radiographic evidence of alveolar bone resorption. They exhibited no sign of inflammation [gingival index $(\mathrm{Gl}=0)$ ]. G group $(n=24)$ had varying degrees of gingival inflammation $(G I \geq 1)$, $P D \leq 3 \mathrm{~mm}$ with no clinical attachment loss (CAL) or with no alveolar bone destruction. The CP group $(n=24)$ was defined as those who were with PD $\geq 4$ $\mathrm{mm}, \mathrm{CAL} \geq 2 \mathrm{~mm}$, and who had bone loss affecting $>30 \%$ of the existing teeth on clinical and radiographic examination.

\section{Clinical Assessment}

The clinical evaluation was performed by measurements of plaque index (PI), GI, PD, and CAL. All these measurements were evaluated at six areas for each tooth (mesio-buccal, mid-buccal, disto-buccal, mesio-lingual, mid-lingual, and distolingual) with a manual periodontal probe (Hu-Friedy) by a single calibrated examiner (T.A.). Calibration of intra-examiner was provided by the evaluation of 10 participants with CP. All patients were measured the PD at 6 areas of each tooth in the maxilla every 3 days by the examiner for 3 times prior to study initiation. PD measurements were evaluated and the reproducibilities of intra-examiner in terms of the interclass correlation coefficient was 0.95 . 


\section{Collection of Saliva, Gingival Crevicular Fluid and Serum Samples}

Saliva, serum, and GCF sampling were applied in the morning hours 2 days after the clinical periodontal measurements. Patients were advised to brush their teeth, not drink anything, or not eat one hour before sampling. All saliva samples were obtained using the unstimulated saliva collection procedure. By giving polypropylene tubes to each patient, about $2 \mathrm{~mL}$ of a saliva sample were taken directly in the tube, and by closing the lid of the tubes immediately, it was centrifuged (Nüve NF 800 R, Ankara, Turkey) at $1000 \mathrm{rpm}$ for 10 minutes at $4{ }^{\circ} \mathrm{C}$ to remove cellular elements and plaque. Then, it was immediately frozen and stored at $-80^{\circ} \mathrm{C}$ until analyses.

In whole groups, GCF samples were collected from the buccal sides of mesial or distal aspects of two single-root teeth by the same periodontist (T.A.). GCF was collected from areas that showed no clinical signs of inflammation in group $\mathrm{H}$. In group $\mathrm{G}$, tooth areas showing GI >1, but no CAL was chosen for GCF sampling. In group $\mathrm{CP}, \mathrm{GCF}$ was accumulated from sites with the highest probing depth and radiographic confirmation of alveolar bone loss showing $\mathrm{Gl}>1$. At selected sites for GCF sampling, the supragingival plaque was removed with a sterile curette, isolated with sterile cotton rolls, and the teeth were lightly air dried. Paper strips (Periopaper ${ }^{\mathrm{TM}}$ Oraflow Inc. Plainview, NY, USA) were placed carefully into the gingival sulcus and were left in position for 30 seconds. Strips contaminated with blood or saliva were rejected. GCF volume of the per strip was measured with a calibrated electronic device (Periotron 8000, Oraflow). The strips were then transferred to sterile polypropylene tubes containing $300 \mu$ of phosphate buffered saline, frozen and stored at $-80^{\circ} \mathrm{C}$ until analysis.

From all study participants, at baseline and after nonsurgical periodontal treatment, $6 \mathrm{~mL}$ of venous blood was collected from the anterocubital vein using the standard venipuncture method. Serum was isolated by centrifugation at $3000 \mathrm{rpm}$ for 5 minutes at $4{ }^{\circ} \mathrm{C}$ and then stored at $-80^{\circ} \mathrm{C}$ until analyses.

\section{Nonsurgical Periodontal Treatment}

After baseline serum, GCF and saliva sampling, ultrasonic scaling therapy was performed in group $G$ and group CP. Oral hygiene education, including the use of toothbrushes and dental floss and/or interproximal brushes, was given to them. One week later, non-surgical periodontal treatment consisting of SRP (quadrant to quadrant) using manuel curettes and scalers was applied to the CP group under local anesthesia. No antibiotics or any medications were prescribed during the treatment. Periodontal therapy was applied by the same researcher (T.A.). Clinical periodontal measurements and GCF, serum and saliva samples were repeated eight weeks after periodontal therapy in group $\mathrm{G}$ and group $\mathrm{CP}$.

\section{Measurements of Biochemical Mediators}

Enzyme-linked immunosorbent assay kits measured GCF, serum and saliva IL-11 (Ray Bio, Norcross, GA.), LIF (eBioscience, Bender Medsystems, Vienna, Austria.), and OSM (Ray Bio, Norcross, GA.) levels. Analyses were performed according to the manufacturer's instructions and using 96-well plates pre-coated with appropriate antibodies. The lower detection verges for IL-11, OSM, and LIF assays were 3.0, 1.0, and $0.3 \mathrm{pg} / \mathrm{mL}$, respectively. The optical densities were read at $450 \mathrm{~nm}$. Results were computed using the standard curves composed in each assay. Concentrations of the cytokines were described as $\mathrm{pg} / \mathrm{mL}$.

\section{Statistical Analysis}

The minimum sample size was performed based on a previous study (42) regarding the GCF levels of the OSM type cytokines and admitting a power of $80 \%$ and $p=0.05$ in study groups. It was determined that the appropriate sample size should be a minimum of 22 for each group. The data were evaluated using the SPSS for Windows 18.0 (SPSS Inc., Chicago, USA) software program. The significance level was considered as $p<0.05$ in statistical analysis. The arithmetic values given according to the groups were indicated by mean \pm standard deviation. Whether distribution was normal and homogeneity of variances were controlled by the Kolmogorov-Smirnov test and Levene test, separately. After the normality and homogeneity assumptions were provided, One-Way ANOVA and post-hoc Duncan multiple comparison tests were used to compare independent groups, whereas the Paired Samples t-test compared dependent groups. Pearson's correlation test was employed to evaluate the correlations of laboratory and clinical parameters with each other. 


\section{Results}

\section{Clinical Findings}

Demographics are presented in Table 1. All clinical periodontal values were significantly higher in group $\mathrm{CP}$ compared with groups $\mathrm{H}$ and $\mathrm{G}$. $\mathrm{Gl}, \mathrm{PI}$, and $\mathrm{PD}$ scores were significantly higher in group $\mathrm{G}$ compared with group $H(p<0.05)$. Average GCF volume varied significantly between groups $(p<0.05)$. Clinical parameters and GCF volume are presented in Table 2.

GCF volumes and the mean values of clinical periodontal parameters, at baseline and after nonsurgical periodontal treatment in group $G$ and group CP, are given in Table 3. GCF volume and all clinical parameters, except CAL, decreased statistically significantly after SRP in group $G(p<0.05)$. Likewise, after SRP, GCF volume and all clinical parameters decreased statistically in patients with $C P(p<0.05)$.

\begin{tabular}{|l|l|l|l|l|}
\hline \multicolumn{3}{|c|}{ Table 1. Demographic data of the groups in our study } \\
\cline { 3 - 5 } & & Age & Gender \\
\cline { 3 - 5 } & & Female & Male \\
\hline Group H & 24 & $30.86 \pm 1.7$ & 12 & 12 \\
\hline Group G & 24 & $34.14 \pm 7.15$ & 11 & 13 \\
\hline Group CP & 24 & $37.24 \pm 7.86$ & 10 & 14 \\
\hline G: Gingivitis, CP: Chronic periodontitis, H: Healthy \\
\hline
\end{tabular}

\section{Laboratory Findings}

Laboratory findings are presented in Table 4. GCF and salivary OSM levels of group $G$ were significantly higher than group $H(p<0.05)$. Compared to group $G$, GCF and serum OSM levels of group CP were significantly higher $(p<0.05)$. It was also remarkable that GCF, serum, and saliva OSM levels of group CP were significantly higher than group $\mathrm{H}(\mathrm{p}<0.05)$.

There were significantly higher GCF LIF levels of group CP than group $H(p<0.05)$. LIF levels in serum and saliva did not differ significantly between the groups ( $p>0.05$ ).

Group CP had significantly higher levels of GCF IL-11 than group $G(p<0.05)$. Compared with group $\mathrm{CP}$, group $\mathrm{H}$ had lower levels of GCF and saliva IL-11 $(p<0.05)$. There were no significant differences in serum IL-11 levels between the study groups ( $p>0.05$ ).

Before and after periodontal therapy, mean values of GCF, serum and saliva OSM, IL-11 and LIF levels in group $\mathrm{G}$ and group $\mathrm{CP}$ and comparison of these values between groups are presented in Table 5 .

Group $\mathrm{G}$ results showed statistically significant decreases in both GCF and saliva OSM, LIF and IL11 levels after periodontal treatment compared to baseline $(p<0.05)$.

In group CP, GCF and saliva OSM and IL-11 levels were significantly reduced after nonsurgical periodontal treatment $(p<0.05)$. Similarly, serum

Table 2. Comparison of clinical parameters and GCF volume between groups $\mathrm{H}, \mathrm{G}$ and CP

\begin{tabular}{|l|l|l|l|l|l|}
\hline Groups & PI & GI & CAL (mm) & PD (mm) & GCF volume \\
\hline H & $1.39 \pm 0.38$ & $0 \pm 0.00$ & $0 \pm 0.00$ & $1.62 \pm 0.17$ & $0.03 \pm 0.01$ \\
\hline G & $2.52 \pm 0.28^{\dagger}$ & $2.0 \pm 0.23^{+}$ & $0 \pm 0.00$ & $2.63 \pm 0.51^{\dagger}$ & $0.13 \pm 0.05^{+}$ \\
\hline CP & $3.82 \pm 0.63^{\ddagger}$ & $2.28 \pm 0.35^{\ddagger}$ & $5.70 \pm 1.23^{\ddagger}$ & $6.50 \pm 1.84^{\ddagger}$ & $0.38 \pm 0.07^{\ddagger}$ \\
\hline
\end{tabular}

${ }^{\dagger}$ Significant difference from the $\mathrm{H}$ group, ${ }^{\ddagger}$ Significant difference from the $\mathrm{H}$ and $\mathrm{G}$ groups, PI: Plaque index, GI: Gingival index, CAL: Clinical attachment loss, PD: Probing depth, GCF: Gingival crevicular fluid, G: Gingivitis, CP: Chronic periodontitis, H: Healthy

\begin{tabular}{|c|c|c|c|c|c|}
\hline & \multirow{2}{*}{ PI } & \multirow{2}{*}{ GI } & \multirow{2}{*}{ CAL (mm) } & \multirow{2}{*}{ PD (mm) } & \multirow{2}{*}{\begin{tabular}{|l} 
GCF \\
Volume $(\mu \mathrm{l})$
\end{tabular}} \\
\hline & & & & & \\
\hline Group G & $2.52 \pm 0.28$ & $2.00 \pm 0.23$ & $0.00 \pm 0.00$ & $2.63 \pm 0.51$ & $0.13 \pm 0.05$ \\
\hline After therapy & $1.13 \pm 0.56^{+}$ & $0.38 \pm 0.40^{+}$ & $0.00 \pm 0.00$ & $2.01 \pm 1.51^{+}$ & $0.03 \pm 0.01^{+}$ \\
\hline Group CP & $3.82 \pm 0.63$ & $2.28 \pm 0.35$ & $5.70 \pm 1.23$ & $6.50 \pm 1.84$ & $0.38 \pm 0.07$ \\
\hline After therapy & $1.17 \pm 0.52^{\ddagger}$ & $0.42 \pm 0.48^{\ddagger}$ & $2.42 \pm 1.76^{\ddagger}$ & $3.62 \pm 1.71^{\ddagger}$ & $0.07 \pm 0.01^{\ddagger}$ \\
\hline
\end{tabular}


OSM levels were significantly lower after periodontal treatment $(p<0.05)$.

\section{Correlations}

Correlations are presented in Table 6. There was no statistically significant correlation between the terms of clinical parameters and laboratory parameters in group $H$. In group $G$, there was a significant and positive correlation between PI and GCF IL-11 levels and between CAL and saliva LIF levels.

In group $\mathrm{CP}$, there was a positive significant correlation between PI and GCF OSM; also, the saliva OSM level was correlated with CAL. The PI level was

\begin{tabular}{|c|c|c|c|}
\hline & GCF (pg/mL) & Serum (pg/mL) & Saliva (pg/mL) \\
\hline \multicolumn{4}{|l|}{ OSM } \\
\hline Group H & $9.61 \pm 4.30$ & $8.33 \pm 5.63$ & $26.60 \pm 19.41$ \\
\hline Group G & $64.30 \pm 46.70^{+}$ & $10.28 \pm 5.54$ & $82.18 \pm 42.93^{+}$ \\
\hline Group CP & $253.60 \pm 97.41^{\ddagger}$ & $72.51 \pm 38.67^{ \pm}$ & $86.54 \pm 32.33^{\ddagger}$ \\
\hline \multicolumn{4}{|l|}{ LIF } \\
\hline Group H & $8.78 \pm 0.82$ & $9.04 \pm 2.29$ & $10.13 \pm 3.51$ \\
\hline Group G & $8.89 \pm 1.60$ & $9.50 \pm 2.68$ & $10.53 \pm 5.26$ \\
\hline Group CP & $13.20 \pm 4.07^{\ddagger}$ & $10.21 \pm 4.44$ & $11.33 \pm 5.90$ \\
\hline \multicolumn{4}{|l|}{ IL-11 } \\
\hline Group H & $32.81 \pm 16.07$ & $34.34 \pm 24.80$ & $32.51 \pm 14.27$ \\
\hline Group G & $40.41 \pm 15.62$ & $35.73 \pm 21.10$ & $61.84 \pm 24.53$ \\
\hline Group CP & $109.30 \pm 41.17^{\ddagger}$ & $43.07 \pm 32.10$ & $84.68 \pm 32.34^{+}$ \\
\hline
\end{tabular}

Table 5. Comparison levels of GCF, serum and saliva OSM, LIF and IL-11 and the statistical comparison of these values between groups before and after periodontal therapy in groups $\mathbf{G}$ and $\mathrm{CP}$

\begin{tabular}{|c|c|c|c|}
\hline & GCF (pg/mL) & Serum (pg/mL) & Saliva (pg/mL) \\
\hline \multicolumn{4}{|l|}{ OSM } \\
\hline Group G & $64.30 \pm 46.70$ & $10.28 \pm 5.54$ & $82.18 \pm 42.93$ \\
\hline After therapy & $16.64 \pm 5.05^{\dagger}$ & $9.73 \pm 6.44$ & $48.18 \pm 14.96^{+}$ \\
\hline Group CP & $253.60 \pm 97.41$ & $72.51 \pm 38.67$ & $86.54 \pm 32.33$ \\
\hline After therapy & $21.64 \pm 9.05^{\ddagger}$ & $28.77 \pm 9.46^{\ddagger}$ & $52.28 \pm 12.97^{\ddagger}$ \\
\hline \multicolumn{4}{|l|}{ LIF } \\
\hline Group G & $8.89 \pm 1.60$ & $9.50 \pm 2.68$ & $10.53 \pm 5.26$ \\
\hline After therapy & $5.42 \pm 3.16^{+}$ & $8.96 \pm 3.43$ & $6.06 \pm 2.52^{+}$ \\
\hline Group CP & $13.20 \pm 4.07$ & $10.21 \pm 4.44$ & $11.33 \pm 5.90$ \\
\hline After therapy & $8.42 \pm 3.10^{\ddagger}$ & $10.04 \pm 4.34$ & $10.20 \pm 4.63$ \\
\hline \multicolumn{4}{|l|}{ IL-11 } \\
\hline Group G & $40.41 \pm 15.62$ & $35.73 \pm 21.10$ & $61.84 \pm 24.53$ \\
\hline After therapy & $24.42 \pm 12.36^{+}$ & $34.56 \pm 18.66$ & $32.12 \pm 14.58^{+}$ \\
\hline Group CP & $109.30 \pm 41.17$ & $43.07 \pm 32.10$ & $84.68 \pm 52.34$ \\
\hline After therapy & $54.62 \pm 10.40^{\ddagger}$ & $39.24 \pm 22.61$ & $40.16 \pm 17.59^{\ddagger}$ \\
\hline
\end{tabular}




\begin{tabular}{|c|c|c|c|}
\hline & & r & $p$ \\
\hline \multirow{2}{*}{ Group G } & PI-GCF IL-11 & 0.534 & 0.03 \\
\hline & CAL-Saliva LIF & 0.450 & 0.02 \\
\hline \multirow{4}{*}{ Group CP } & PI-GCF OSM & 0.468 & 0.03 \\
\hline & PI-Saliva LIF & -0.487 & 0.03 \\
\hline & PI-Saliva IL-11 & -0.445 & 0.05 \\
\hline & CAL-Saliva OSM & 0.472 & 0.03 \\
\hline Group CP & PI-Saliva OSM & -0.680 & 0.002 \\
\hline After therapy & GI-Saliva OSM & -0.514 & 0.02 \\
\hline
\end{tabular}

determined to be negatively correlated with saliva LIF, IL-11, and OSM levels. In group CP, a statistically significant negative correlation existed between saliva OSM and GI.

\section{Discussion}

The interaction between the pathogenic bacteria in the microbial dental plaque and the host response mechanism causes periodontal destruction. The host response stimulated by bacteria protects periodontal tissues, which are also destroyed simultaneously. Recent studies have focused on indirect mechanisms that play a role in periodontal diseases (17-19).

$\mathrm{PI}, \mathrm{GI}, \mathrm{PD}$, and CAL measurements and radiographic techniques, which are used to evaluate periodontal tissue destruction and periodontal treatment success, are the most important parameters in determining the intensity of the disease and the level of success achieved with treatment. This study revealed that participants with periodontal disease had higher PI, GI, PD and CAL parameters than healthy participants. Our study findings are in line with the results of many studies conducted to date (20-23).

Afacan et al. (24), in their study, reported that there was a positive correlation between periodontal inflammation and GCF volume. Some researchers have also demonstrated that the GCF volume decreases after periodontal therapy $(25,26)$. GCF volume showed a statistically significant decrease in our study, too, eight weeks after nonsurgical periodontal therapy.

In periodontal diseases, inflammatory changes caused by bacterial biofilm lead to changes in biochemical marker levels in various body fluids such as GCF, serum, and saliva (27). It has been known that measuring these biochemical markers' levels in these fluids provides diagnostic, therapeutic, and prognostic benefits by contributing to clinical index systems in various diseases $(27,28)$. Our study investigated the presence and levels of inflammatory cytokines such as OSM, LIF, and IL-11 in saliva for the first time. Previous studies have examined them in GCF and serum, but not in saliva.

Many cytokines found in GCF, mainly proinflammatory and inflammatory cytokines, have been shown as diagnostic or prognosis markers in periodontal destruction (29). A variety of cytokines from the IL- 6 family are involved in this inflammatory process and stimulate various cellular responses (30). In the current study, GCF, serum, and saliva OSM levels were higher in participants with periodontal disease than in healthy subjects.

Various studies in the literature have addressed that OSM can be thought of as an inflammatory biomarker in periodontal diseases, and this cytokine may play a role in alveolar bone resorption $(31,32)$. In addition, it is thought that the reason for the increase in serum OSM level in CP patients may be the spread from diseased periodontal tissues or GCF to the systemic circulation or the systemic inflammatory response that develops against periodontal disease (31). The present study is the first study to show OSM's presence in saliva in periodontally healthy and sick individuals. High OSM levels in participants with periodontal disease in our study support the view that this cytokinin can be considered an inflammatory biomarker in periodontal diseases. 
In their study on healthy individuals with periodontal disease, Becerik et al. (33) reported that there was no difference in GCF OSM levels in the comparison between the groups. Naemura and Radka (34) could not detect plasma and serum OSM levels in healthy individuals in a study they conducted. They reported the reason for this as the difference in the role of OSM on soft and hard tissue destruction in the periodontium (32). These results are not compatible with the results of our study. It can be said that the reason for this incompatibility is due to material and method differences in related studies.

While the presence of LIF in GCF, serum, and saliva was determined in all our study participants, GCF LIF level was found to be higher in those with periodontal disease than healthy subjects. Sakai et al. (35) indicated LIF in gingival tissue samples in 6 out of 7 patients with $\mathrm{CP}$ and 4 out of 7 periodontally healthy individuals. Palmqvist et al. (36) confirmed the presence of LIF in human gingival fibroblasts in their in vitro study. In an animal study, LIF was shown to stimulate osteoclast formation (10). Our study is the first study investigating the presence and levels of serum and saliva LIF as far as we know. Previous studies suggest that high LIF levels in individuals with periodontal disease can play a role in active tissue destruction and be considered an inflammatory biomarker. Becerik et al. (33) stated that the GCF LIF level was higher in healthy individuals than in periodontal disease subjects. They also reported that this result might be due to the LIF's regulatory role in alveolar bone metabolism and protective role in the host response to infection.

It has been shown that IL-11 is an important member of the cytokine group that controls osteoclast development and has different properties compared to other cytokines. IL-11 plays a crucial role in osteoclast formation (37). It has been reported that IL-11 increases bone resorption and stimulates osteoclast-mediated mineral mobilization by a mechanism dependent on prostaglandin E2 synthesis, and also causes bone matrix damage in mice $(38,39)$. Becerik et al. (33) suggested that GCF IL-11 levels were lower in healthy persons than in persons with $\mathrm{CP}$, and they showed a positive correlation with pocket depth and clinical attachment level. Similarly, in the current study, GCF IL-11 levels were lower in healthy persons than in CP patients. Based on our study results, we think that IL-11 can play a crucial role in active tissue destruction and alveolar bone resorption throughout the periodontal disease process.

Similar to our study results, in their studies on individuals with CP, Johnson et al. (40) reported that IL11 concentration was higher in areas with less pocket depth and this concentration decreased in parallel with the increase in pocket depth, and the lowest IL-11 concentrations were in healthy gingival tissue. Unlike our findings, other studies demonstrating lower GCF IL-11 levels in individuals with CP than healthy subjects are also available. Guided by all these study data, it has been suggested that IL-11 may have a protective and anti-inflammatory effect in the pathogenesis of periodontal diseases, and play a key role in preventing progressive inflammation that can cause periodontal tissue destruction. It has also been stated that low IL11 levels in $\mathrm{CP}$ patients with high pocket depth may be due to the decreased protective effect of IL-11 on periodontal lesions or the episodic characteristic of periodontal disease $(12,41)$. The present study, at the same time, is of great importance in terms of being the first study to show the presence of IL-11 in saliva and serum. We believe that differences in all study results in the literature may have originated from genetic variations that disrupt the inflammatory mechanism and individual differences in immune response and severity of the clinically observed inflammation.

Our study revealed a significant decrease in serum and saliva OSM, LIF, and IL-11 levels in group $\mathrm{G}$ and group $\mathrm{CP}$ after nonsurgical periodontal therapy. Likewise, Thorat et al. reported decreased GCF and serum OSM levels in CP patients after nonsurgical periodontal treatment $(32,42)$. In their study carried out with 60 individuals, Pradeep et al. (31) found that serum OSM levels decreased after initial periodontal treatment in individuals with $\mathrm{CP}$.

Recent study has only evaluated OSM, IL-11, and LIF levels; but chronic inflammatory diseases like periodontitis also include other cytokines. Therefore, further work will be beneficial to investigate the relationship between these three cytokines and others. Within the limitations of this study; we have shown that IL-11, LIF and OSM may play a role as inflammatory biomarkers in the pathogenesis of periodontal disease. Additional researches may reveal the roles of IL-11, LIF and OSM in the pathogenesis 
of $\mathrm{CP}$ and the relation with systemic conditions such as atherosclerosis, rheumatoid arthritis, and diabetes.

\section{Conclusion}

With the present study, it was introduced that there was a close relationship between periodontal clinical and biochemical parameters and that clinical improvement affected biochemical parameters. Besides, the reduction in GCF volume due to treatment was reflected in clinical and biochemical parameters. The mechanisms that enable pro-inflammatory cytokines involved in the pathogenesis of periodontal disease to activate collagen degradation and loss of attachment and bone destruction are still not fully clarified. For illuminating all these processes, which will enable rapid diagnosis of the disease and increase the effectiveness of the treatment to be applied, further and comprehensive studies are needed.

\section{Ethics}

Ethics Committee Approval: This study was performed after Atatürk University Faculty of Dentistry Ethics Committee (decision no: 22/2014, date: 01.08.2014) approval was obtained.

Informed Consent: Informed consent form was given to each individual.

Peer-review: Externally peer-reviewed.

\section{Authorship Contributions}

Concept: A.D., T.A., Design: A.D., T.A., Supervision: A.D., T.A., Materials: T.A., Data Collection or Processing: T.A., Analysis or Interpretation: T.A., Literature Search: T.A., Writing: T.A., Critical Review: A.D., T.A.

Conflict of Interest: No conflict of interest was declared by the authors.

Financial Disclosure: This research was supported by the Scientific Research Foundation of Ataturk University (grant 2011/298).

\section{References}

1. Kornman KS, Page RC, Tonetti MS. The host response to the microbial challenge in periodontitis: assembling the players. Periodontol 2000 1997; 14: 33-53.

2. Hart TC, Kornman KS. Genetic factors in the pathogenesis of periodontitis. Periodontol 2000 1997; 14: 202-15.

3. Birkedal-Hansen $H$. Role of cytokines and inflammatory mediators in tissue destruction. J Periodontal Res 1993; 28: 50010.

4. Sims NA, Walsh NC. GP130 cytokines and bone remodelling in health and disease. BMB Rep 2010; 43: 513-23.
5. Rose-John S. Interleukin-6 Family Cytokines. Cold Spring Harb Perspect Biol 2018; 10: a028415.

6. Behrmann I, Hermanns HM, Haan C, Kortylewski M, Radtke S, Greiser J, et al. Signalling of interleukin-6 type cytokines via gp130, leukemia inhibitory factor (LIF) receptor and oncostatin M receptor. Eur Cytokine Netw 2000; 11: 491-2.

7. Manicourt DH, Poilvache P, Van Egeren A, Devogelaer JP, Lenz ME, Thonar EJ. Synovial fluid levels of tumor necrosis factor alpha and oncostatin $\mathrm{M}$ correlate with levels of markers of the degradation of crosslinked collagen and cartilage aggrecan in rheumatoid arthritis but not in osteoarthritis. Arthritis Rheum 2000; 43: 281-8.

8. Lin SJ, Chen YL, Kuo MY, Li CL, Lu HK. Measurement of gp130 cytokines oncostatin $\mathrm{M}$ and IL-6 in gingival crevicular fluid of patients with chronic periodontitis. Cytokine 2005; 30: 160-7.

9. Martin TJ, Romas E, Gillespie MT. Interleukins in the control of osteoclast differentiation. Crit Rev Eukaryot Gene Expr 1998; 8: 107-23.

10. Palmqvist $\mathrm{P}$, Persson E, Conaway HH, Lerner UH. IL-6, leukemia inhibitory factor, and oncostatin $\mathrm{M}$ stimulate bone resorption and regulate the expression of receptor activator of NF-kappa B ligand, osteoprotegerin, and receptor activator of NF-kappa B in mouse calvariae. J Immunol 2002; 169: 3353-62.

11. Richards CD, Langdon C, Deschamps P, Pennica D, Shaughnessy SG. Stimulation of osteoclast differentiation in vitro by mouse oncostatin $\mathrm{M}$, leukaemia inhibitory factor, cardiotrophin-1 and interleukin 6: synergy with dexamethasone. Cytokine 2000; 12: 613-21.

12. Yücel OO, Berker E, Gariboğlu S, Otlu H. Interleukin-11, interleukin-1beta, interleukin-12 and the pathogenesis of inflammatory periodontal diseases. J Clin Periodontol 2008; 35: 365-70.

13. Hill GR, Cooke KR, Teshima T, Crawford JM, Keith JC Jr, Brinson YS, et al. Interleukin-11 promotes $T$ cell polarization and prevents acute graft-versus-host disease after allogeneic bone marrow transplantation. J Clin Invest 1998; 102: 115-23.

14. Hermann JA, Hall MA, Maini RN, Feldmann M, Brennan FM. Important immunoregulatory role of interleukin-11 in the inflammatory process in rheumatoid arthritis. Arthritis Rheum 1998; 41: 1388-97.

15. Ozmeric N. Advances in periodontal disease markers. Clin Chim Acta 2004; 343: 1-16.

16. Armitage GC. Development of a classification system for periodontal diseases and conditions. Ann Periodontol 1999; 4: 1-6.

17. Kinane DF, Bartold PM. Clinical relevance of the host responses of periodontitis. Periodontol 2000 2007; 43: 278-93.

18. Pan W, Wang Q, Chen Q. The cytokine network involved in the host immune response to periodontitis. Int J Oral Sci 2019; 11: 30.

19. Silva N, Abusleme L, Bravo D, Dutzan N, Garcia-Sesnich J, Vernal $R$, et al. Host response mechanisms in periodontal diseases. J Appl Oral Sci 2015; 23: 329-55. 
20. Lindhe J, Westfelt E, Nyman S, Socransky SS, Haffajee AD. Longterm effect of surgical/non-surgical treatment of periodontal disease. J Clin Periodontol 1984; 11: 448-58.

21. van Oosten MA, Mikx FH, Renggli HH. Microbial and clinical measurements of periodontal pockets during sequential periods of non-treatment, mechanical debridement and metronidazole therapy. J Clin Periodontol 1987; 14: 197-204.

22. Badersten A, Nilvéus R, Egelberg J. Effect of nonsurgical periodontal therapy. I. Moderately advanced periodontitis. J Clin Periodontol 1981; 8: 57-72.

23. Al-Isa $M$, Alotibi $M$, Alhashemi $H$, Althobiani $F$, Atia A, Baz S. Effect of non-surgical periodontal therapy on the fibrinogen levels in chronic periodontitis patients. Saudi Dent J 2019; 31: 188-93.

24. Afacan B, Öztürk VÖ, Paşalı Ç, Bozkurt E, Köse T, Emingil G. Gingival crevicular fluid and salivary HIF-1 $\alpha$, VEGF, and TNF- $\alpha$ levels in periodontal health and disease. J Periodontol 2019; 90: 788-97.

25. Furuse N, Takai H, Ogata Y. Effects of Initial Periodontal Therapy on Heat Shock Protein 70 Levels in Gingival Crevicular Fluid from Periodontitis Patients. J Clin Med 2020; 9: 3072.

26. Karsiyaka Hendek M, Kisa U, Olgun E. The effect of smoking on gingival crevicular fluid peptidoglycan recognition protein-1 level following initial periodontal therapy in chronic periodontitis. Oral Dis 2020; 26: 166-72.

27. Lee A, Ghaname CB, Braun TM, Sugai JV, Teles RP, Loesche WJ, et al. Bacterial and salivary biomarkers predict the gingival inflammatory profile. J Periodontol 2012; 83: 79-89.

28. Salminen A, Gursoy UK, Paju S, Hyvärinen K, Mäntylä P, Buhlin $K$, et al. Salivary biomarkers of bacterial burden, inflammatory response, and tissue destruction in periodontitis. J Clin Periodontol 2014; 41: 442-50.

29. Kamma J, Mombelli A, Tsinidou K, Vasdekis V, Giannopoulou C. Cytokines in gingival crevicular fluid of adolescents and young adults. Oral Microbiol Immunol 2009; 24: 7-10.

30. Orozco A, Gemmell E, Bickel M, Seymour GJ. Interleukin 18 and periodontal disease. J Dent Res 2007; 86: 586-93.
31. Pradeep AR, S TM, Garima G, Raju A. Serum levels of oncostatin $M$ (a gp 130 cytokine): an inflammatory biomarker in periodontal disease. Biomarkers 2010; 15: 277-82.

32. Thorat M, Pradeep AR, Garg G. Correlation of levels of oncostatin $M$ cytokine in crevicular fluid and serum in periodontal disease. Int J Oral Sci 2010; 2: 198-207.

33. Becerik S, Öztürk VÖ, Atmaca H, Atilla G, Emingil G. Gingival crevicular fluid and plasma acute-phase cytokine levels in different periodontal diseases. J Periodontol 2012; 83: 1304-13.

34. Naemura JR, Radka SF. Detection of oncostatin $M$ in human plasma and serum by a sensitive enzyme immunoassay. Lymphokine Cytokine Res 1993; 12: 187-90.

35. Sakai A, Ohshima M, Sugano N, Otsuka K, Ito K. Profiling the cytokines in gingival crevicular fluid using a cytokine antibody array. J Periodontol 2006; 77: 856-64.

36. Palmqvist $P$, Lundberg $P$, Lundgren $I$, Hänström $L$, Lerner $U H$. IL-1beta and TNF-alpha regulate IL-6-type cytokines in gingival fibroblasts. J Dent Res 2008; 87: 558-63.

37. Kitaura H, Marahleh A, Ohori F, Noguchi T, Shen WR, Qi J, et al. Osteocyte-Related Cytokines Regulate Osteoclast Formation and Bone Resorption. Int J Mol Sci 2020; 21: 5169.

38. Ahlen J, Andersson S, Mukohyama H, Roth C, Bäckman A, Conaway $\mathrm{HH}$, et al. Characterization of the bone-resorptive effect of interleukin-11 in cultured mouse calvarial bones. Bone 2002; 31: 242-51.

39. Morinaga $Y$, Fujita N, Ohishi K, Zhang Y, Tsuruo T. Suppression of interleukin-11-mediated bone resorption by cyclooxygenases inhibitors. J Cell Physiol 1998; 175: 247-54.

40. Johnson RB, Wood N, Serio FG. Interleukin-11 and IL-17 and the pathogenesis of periodontal disease. J Periodontol 2004; 75: $37-$ 43.

41. Yetkin Ay Z, Sütçü R, Uskun E, Bozkurt FY, Berker E. The impact of the IL-11:IL-17 ratio on the chronic periodontitis pathogenesis: a preliminary report. Oral Dis 2009; 15: 93-9.

42. Thorat Manojkumar S, Pradeep AR, Garg G, Raju A. Gingival crevicular fluid levels of oncostatin $\mathrm{M}$ in periodontal conditions. Cytokine 2010; 50: 248-52. 